\title{
The Globular Amphora Culture in the Writings of Jan Kowalczyk
}

\author{
Andrzej Bronicki ${ }^{a}$
}

The present paper discusses the scientific and popular science publications by Jan Kowalczyk referring to the Globular Amphora culture and presents the scholar's achievements in acquiring and popularising knowledge about this taxonomic unit.

KEY-WORDS: Globular Amphora culture, genesis, chronology, economy, funeral rites, Neolithic demographics, research methodology, Jan Kowalczyk.

Jan Kowalczyk became interested in the Globular Amphora culture (hereinafter: GAC) in the earliest years of his professional career. Debuting in the scientific literature, he described, among other things, the accidental discovery of an "amphoral" grave at Stok, Puławy district on the Nałęczów Plateau (1949: 136). He maintained this interest until he retired. The last publication related to the topic was an Introduction written for a monographic study of the GAC cemetery in Złota, Sandomierz district (1977: 7-8). In total, there were 24 scientific and popular science texts by this author in which the "amphoral" issue was the leading theme or appeared in the wider context of research into the Neolithic (Zakościelna 1997; Zakościelna and Gurba 2007: 387).

\section{FIELD INVESTIGATION REPORTS}

There are not many direct references to the GAC in the source-literature produced by J. Kowalczyk. In effect the main cases are only the archaeological excavations carried out at GAC cemeteries on the Nałęczów Plateau (Las Stocki and Stok, Puławy dostrict) and in Mazovia (Bieniewo, Warsaw West district). In the cases of the archaeological excavations in the Puławy district, J. Kowalczyk took part in them as a young employee of the Prehistory Department of the Maria Curie-Skłodowska University and of the Department of Archaeology of the Lublin Museum. As to the excavations of Bieniewo he took part in it as a mature researcher in the Department of the Neolithic of the

a Museum of the Chełm Land in Chełm, 55 Lubelska st., 22-I0o Chełm, Poland, e-mail: ba@mzch.pl ORCID: 0000-0002-646I-3952 
I58 $\mid$ Andrzej Bronicki

Archaeological Museum in Warsaw. He also investigated the graves in Klementowice (Kowalczyk 1957: 175; Halicki 1970: 303; Balcer 1998: 4) and in Parchatka (Kowalczyk I964a: I49), both Puławy district .

The report of the excavations at Las Stocki and Stok carried out in I95I under the direction of Stefan Nosek (as part of works started in 1947) is divided into three parts (Kowalczyk 1953). The first two are devoted to two examined features - collective human graves. They contain data on the circumstances of the discovery, description of grave structures (of stone), characteristics of remains of the dead (position, orientation, state of preservation), information on burial furnishing (localisation of items in relation to the skeletons). The noticing of small aggregations of charcoal, as well as small shells in the fill of the grave from Las Stocki evidences the diligence of the conducted work. In the further part of the article there are descriptions of elements of grave furnishing (everyday objects, personal ornaments and animal bones), containing also the dimensions of finds. The whole is complemented by illustrative material: the plan of the grave from Las Stocki and drawings of some artefacts (unfortunately not of all of them). Also lacking is an illustration presenting the partially damaged grave discovered in Stok, which is a significant fault of the report. Drawings of selected artefacts coming from two different graves were unnecessarily mixed up together in the tables. The third part is an analysis of the funeral rite based on two different graves, in a wider comparative context as well as an attempt to interpret the character of the burials. Already then, the young scholar tried to perceive in the feature from Las Stocki a "distinguished" individual among the "sacrifices" brought to him. The article closes with brief comments on the relative chronology of both assemblages. Kowalczyk used the division of the Neolithic into three sub-periods (I-III), whereby he considered the grave from Las Stocki (devoid of ceramics with corded ornamentation and without heart-shaped projectile points) as older than the one from Stok, where these elements occurred. ${ }^{\mathrm{I}} \mathrm{He}$ explains their presence as resulting from contacts with the communities of the Corded Ware culture, which allows us to infer that he treated the latter as coincident with the younger phase of the GAC. An additional research achievement of J. Kowalczyk was the resolution of doubts as to the possibility of using the bow by the population of the GAC, expressed by Józef Kostrzewski (I939-I948: I48). The presence of projectile points in the tomb from Stok unambiguously solved this matter.

The second report of J. Kowalczyk was written together with Anna Uzarowicz (Uzarowiczowa and Kowalczyk 1973). This is a text discussing the activities undertaken as part of the intervention of the State Archaeological Museum in Bieniewo, West Warsaw district, after the accidental discovery and damage to a tomb of the GAC located there. An area little over $186 \mathrm{~m}^{2}$ was excavated, which allowed the identification

\footnotetext{
${ }^{\mathrm{I}}$ Later, the author acknowledged that the presence of corded ornamentation (or lack of it) does not determine the chronological position (e.g. 1977: 7).
} 
not only of the grave (a cist burial with a cover), a feature in its vicinity and a fire pit, as well as the fairly wide context of these features. The article contains data on the location and description of the megalithic structure, giving its orientation (W-E, with some deviation towards the north) and dimensions, indicating the existence of two concentrations of charcoal outside the burial chamber. The authors describe the bone remains, based on the opinion of the anthropologist Alina Wiercińska, providing determination of sex (woman) and age (juvenis) of the deceased. They provide data on the location of the furnishings of the burial and detailed descriptions of its elements. All items were measured and drawn. In the further part of the study, the authors described the "chamber adjoining the grave" and illustrated it with a site plan. It was found that in the eastern part of the "feature adjoining the grave", an isolated square chamber with traces of charred wooden beams was identified. In its western part, next to the charcoal, two clusters of cow's teeth and seven small fragments of the body of a GAC ceramic vessel were found. In addition, remains of a hearth with a large part of a pot-shape vessel with corded ornamentation were discovered.

In the analytical part, the authors compare the finds from Bieniewo with other artefacts from the Lublin-Mazovian and Warmian-Masurian group of the GAC, but they do not find good analogies. The complex nature of the feature (human grave, chamber with cattle remains and hearth) corresponds most fully to the situation in Zdrojówka, Koło district and to that of the grave II from Rańsk, Szczytno district. The authors are distrustful of the findings of S. Nosek (1967) and Tadeusz Wiślański (1966a) as to the division of the GAC into territorial groups on the basis of differences in ceramics only. According to them, it is necessary to take into account also the form of the grave. Graves made of large stones (megalithic ones), as well as features with the earliest chronology, would be a testimony to the "northern" cradle of this culture. Therefore, according to the authors, the mechanical classification of the feature from Bieniewo to the Mazovian-Lublin group or the Lublin sub-group is not justified. They share an interesting opinion of Lidia Gabałówna - that is, however, difficult to prove - that the burials of a pair of cattle separated from the human remains by an empty space may indicate that the deceased was brought to the grave on a sled or cart drawn by the oxen (cows) that were sacrificed and the vehicle (now completely decayed) had been in what was the empty place found by excavation (Gabałówna 1958: 92). This type of burial was known from the Near East. The article concludes with a deduction - a methodological postulate - to study the broad terrain context surrounding the "amphoral" graves and to return to the study of graves previously discovered, but not in sufficient degree excavated. ${ }^{2}$

2 This postulate was returned to in the theoretical article Źródtoznawcza problematyka archeologii (Kowalczyk 1973: II). 
I6o $\mid$ Andrzej Bronicki

\section{RADIOCARBON DATING}

Jan Kowalczyk was a pioneer in radiocarbon dating. Before 1967, there was only one date for Pit No I8o belonging to the Funnel Beaker culture (hereinafter: TRB) from Ćmielów, Ostrowiec Świętokrzyski district. Two texts were written about the results of the $\mathrm{CI}_{4}$ measurement, referring to two archaeological sites: Gródek on the Bug, Hrubieszów district and Klementowice, Puławy district, which also include the interpretation of the dates obtained (Kowalczyk 1968a; 1968b). The author emphasized the positive role of Jan Albert Bakker, thanks to whom contact was established with the laboratory in Groningen, and of Hermann Schwabedissen, who made it possible to date the samples in Cologne. Another samples examined were those from the sediment of Pit No 13 from Gródek site I C, belonging to the TRB, and from the grave No. 7 from the cemetery in Klementowice, site D/IV/, currently site 4 (Bronicki 2016: 93-IO2). An unique fact is that the material from the grave discovered in Klementowice was dated at the same time in two laboratories: in Cologne - charcoals (KN-255: $2490 \pm 160 \mathrm{BC}$ ) and in Groningen - charred bark (GrN-5046: $2225 \pm 30$ BC). After the calibration made today according to the OxCal v4.2.4 program by Christopher Bronk Ramsey (2009), using the INTCALI3 calibration curve (Reimer et al. 20I3), with a probability of $68.2 \%$, the following dates were obtained: Cologne: 3007-2883 BC, Groningen: 2878-2697 BC (Włodarczak 20I6: 538, Table I). J. Kowalczyk thoroughly described the context of the collected samples: he gave a detailed description of the grave and human remains along with anthropological assessment - and an inventory of the grave furnishing. He also presented the significance of the results for the study of prehistory:

I) The GAC is a taxonomic unit younger than the TRB. At the same time, the possibility of a longer coexistence of both cultures in the same areas should be ruled out. Most likely is the GAC communitie's invasion on the territory occupied by the populations of the TRB. This could definitely have contributed to the disintegration of the older settlements and the culture that they represented. The date from Klementowice would mark the beginning of the "amphoral" settlement, and at the same time the end of the "Funnel Beaker" one in the Lublin region".

2) Finds of the GAC in the south-eastern territories (Volhynia, Podolia) and in the Lublin region belong to its late phase, which excludes the localisation here of the "cradle" of this culture. This statement indicates that by this time, J. Kowalczyk had stopped taking seriously the hypothesis of Vere Gordon Childe (I925) and Marija Gimbutas (1956: I5O-I5I) about the origins of the GAC in the Black Sea area.

3 Compare recent discussions of the chronology of the GAC in the Lublin region (Włodarczak 2016 and Bronicki 2019, with further literature). 


\section{SYNTHESES, MONOGRAPHS}

Neolithic funerary customs occupy an important place in area of interest of J. Kowalczyk, an expression of which was his unpublished doctoral thesis Obrzadek pogrzebowy $w$ mtodszej epoce kamienia na ziemiach polskich [The funeral rite in the Later Stone Age in the Polish lands], defended in I95I (discussion of doctorate: Nosek 1951). The writing of the part referring to the GAC was based largely on the results of research conducted on the Nałęczów Plateau. The post-graduate student noted that the GAC graves are primarily located on eminences. He notes their diversity, from rarely occurring pit graves, to complex megalithic graves with auxiliary stone constructions. $\mathrm{He}$ also finds that graves are more frequently oriented along the E-W axis. Kowalczyk states that almost 50\% of the GAC graves are collective burials. He also perceives a chaotic arrangement of the remains of the dead and cannot discern any regularities in the orientation of the skeletons. He suggests this reveals the lack of rules in this regard. At the same time, he adds that the funeral rite encountered is the phenomenon of "scorching" of the remains of the dead in the graves. He also states that the furnishing of the GAC graves are most often vessels (63\% of graves) and axes. This suggests the possibility of distinguishing some of the dead ("the main individual") for whom others were sacrificed; thus, he polemicized with the prevailing view of the treatment of the collective graves as family burials.

Development of the issue concerning collective graves was presented in a text published II years later (Kowalczyk 1962b). The Author once again took a position on the opinion prevailing at that time that these were family graves (e.g. Kozłowski I92I: I5; Kostrzewski I930: 99). Drawing on the achievements of other scholars and on personal reflection, he presented a different perspective on this issue. It is a view that at least some of the GAC graves contain burials of a "distinguished" individual as well as remains of human sacrifices made on their behalf (cf. Maringer 1942-I945: II2; Nosek I954-I955; Sulimirski 1957-I959: 272). Situations of this type were noted by Kowalczyk in the graves from Borucin and Świerczyn, both localities in the Radziejów district (research by Leon Kozłowski: 192I: Tabl. I and VI), from Pikutkowo, Włocławek district - research by Stanisław Madajski (Jażdżewski 1937: 98) and from Klementowice, Puławy district Cemetery B, Grave I, (research by S. Nosek 1954-I955: 66). He believed that family graves, of course, also existed, but each collective burial requires a detailed analysis to allow its proper qualification. In Kowalczyk's opinion, "distinction" may be marked by the following traits: alignement (position) and localisation of the remains of the "main individual" in comparison to the arrangement of the other dead ("victims"), the quality and quantity of grave goods grouped next to the "distinguished individual". Other hints include, for example, making one part of the burial chamber in a different way than the other parts, e.g. more thoroughly, with additional 
I62 Andrzej Bronicki

stone cobbling or the use of additional stones in the cist surrounding the remains of the "main" deceased.

The scholar claims that among all the graves of the GAC that have been well published, there is no single grave, all are collective graves. It is not possible to agree with this conclusion, however, because now we know many "amphoral" graves containing the remains of single individuals, and they are now known to be quite numerous features of the Eastern Lublin group, studied e.g. in Łopiennik Dolny-Kolonia, Krasnystaw district, Poniatówka, Chełm district and in Sahryń, Stefankowice-Kolonia, Strzyżów, all in the Hrubieszów district (Bronicki 2016).

The sacrificial character of the burials is suggested, according to J. Kowalczyk, by the presence of a double-ended bone point among human remains in Grave No I in Cemetery B in Klementowice - analogically as among the bones of cattle in animal graves (Gabałówna 1958: 92). It is possible that this is an item with which a ritual death was inflicted. It seems that an explication of this type is highly probable in the light of the discovery in Czułczyce-Kolonia, Chełm district, where a perforator made of bone was found stuck between the cervical vertebrae of one of the dead (Bronicki 2000: 185, I87).

An interesting observation of J. Kowalczyk is that the "distinguished" individual could be a woman who was accompanied by "victims" composed of men. A situation of this type occurs in the tomb examined at Las Stocki, in the G cemetery (Kowalczyk 1953: 46; Dzierżykraj-Rogalski 1955: 80-8I).

The scholar's arguments are complemented by traces of cannibalism being found within the same feature. A human skull with traces that were hypothesized as a "result of frying the brain in the calotte" appeared here (Dzierżykraj-Rogalski 1948: 25I), as well as split long bones (with the aim to extract the marrow?) and traces of their "scorching".

At the same time, a text of monographic and popular-scientific character, Lud kultury amfor kulistych [The People of the Globular Amphora culture] was published by J. Kowalczyk in two subsequent cahiers of $Z$ otchtani wieków (Kowalczyk 1964a; 1964b). It has been written in the form of a spoken story. It refers only to the GAC, whose community the author includes among the ancestors of contemporary Poles. The article begins in a journalist style with a report on the many years of excavations carried out in the Nałęczów Plateau, in which the author participated. He repeats here in an approachable manner his opinions, which had been expressed in more serious form in other publications. He believes that the grave with four skeletons excavated in Klementowice (in 1950) had been constructed at one time for the four occupants who had died at the same time. A double-ended bone point, found for the first time in Europe in a human grave, suggested that some individuals could have been killed with its help. These would be "sacrifices" for a "distinguished", central person. At the tomb at Parchatka, examined a year before, such a "point of death" was also found 
among the skeletons of cows. J. Kowalczyk supposes that the young woman buried in this grave could have been the wife of a "distinguished" man and died to accompany her husband on the journey to the afterlife. He mentions analogies from the Kuyavia region (Świerczyn, Borucin grave II) and from Mazovia (Potyry, Płońsk district: Sawicki 1920). The tomb at Las Stocki probably also contained the remains of a "distinguished" individual - a young woman with an infant for whom two men were sacrificed, which may indicate the important position of women in the GAC communities. Kowalczyk noted that this fact would be inconsistent with the patriarchal model, usually dominant among nomads. In the further part of the article the elements of the grave goods were discussed: vessels (with food), tools, weapons, personal ornaments, elements of carcases, sometimes in the form of jawbones of a wild boar, which could be a totem animal, sometimes whole or almost whole cows, found also in separate animal graves. This dual character of the burials renders interpretation difficult, because a separate grave of a bovine may be testimony to the "deification" of the cow (analogical to ancient Egypt), while the presence of cattle remains in a human grave may indicate that cattle formed a part of grave goods.

The Author emphasizes the destructive and grim role of the GAC communities in prehistory. He connects the disappearance of the FBC with attacks from the GAC, as evidenced by the burning of the settlement in Gródek. The period of dominance of the TRB communities is referred by him to as the "golden age of the Stone Age", and the GAC communities - as "Vikings of the Neolithic". ${ }^{4}$ The argument supporting this reasoning is the fact that in Klementowice one of the "amphoral" graves has damaged a "beaker one", which testifies to the earlier chronology of the latter and the fact that the GAC community found itself in an environment previously exploited by the TRB.

In the rest of the story, the scholar describes the GAC settlement in Mierzanowice, Opatów district - the first one in Poland - discovered in 1935 by Kazimierz Salewicz. The lack of traces of buildings leads to the conclusion that huts had stood there, and these constituted the basic form of residential construction of nomadic shepherds stock herders of cattle and pig as well as of sheep and goats. He wonders whether the GAC community knew agricultural cultivation of cereals. He leaves this matter open.

${ }^{4}$ In an earlier popular-scientific text (I959b: 172), J. Kowalczyk suggests that in antiquity (in Neolithic times), the Lublin region served as an important bridge in contacts between the Vistula lands and the cultural centres of the Near East, which were a land densely populated, with bustling large "settlement centres". The TRB was a group that exhibited a high level of cultural development, living in wooden and clay houses built on the surface of the earth (and not in dugouts, as among early Slavs 3000 years later), equipped with copper metallurgy. They were the owners of large cattle herds and producers of grain. Prosperity ended abruptly due to some movements of the population, when a large settlement in Gródek nad Bugiem was burnt, the seats of the Tripolye culture and Troy II were destroyed and the Hittite state came into existence in Anatolia. One can guess that the author, in the case of the burning of Gródek, has in mind the GAC aggressors, although this name was not mentioned. 
I64 Andrzej Bronicki

He also draws attention to the possibility of exploitation of the banded flint (in the mine in Krzemionki Opatowskie [Krzemionki, Ostrowiec Świętokrzyski district]), which was used to make the famous wholly polished axes that were to be found in graves. However, he also does not prejudge this matter, presenting the hypothesis that it is just as possible that anyone else could have mined flint for export for the GAC community. He mentions the production of tools of bone (e.g. double-ended points known from graves) and of ceramics, critically assessing its poor technology, and highly appreciating the ornaments. He concludes that the clay vessels were not very important in the nomads' life, equipped probably also with containers of leather and wood. The poor technology of ceramics may - in his opinion - indicate the connexion of the GAC with the zone of the lowland forests, remaining in opposition to the loess zone of the old uplands, where good quality vessels were produced from the beginning of the Neolithic.

The phenomenon of the widespread use of amber, treated as a favourite raw material for the production of personal ornaments, can be interpreted as a reminiscence of a longer stay of the GAC communities on the shores of the Baltic sea, which may be important in considering the genesis of this taxonomic unit. Kowalczyk also speculates about the meaning of amber beads in the shape of a double shaft-hole axe, which can be interpreted as some form of relation with a thundering deity, and the use of fire can be combined with solar beliefs (in favour of the existence of which in these communities is the presence of the "sunny" ornament on the cover found in Grave II at Las Stocki, in cemetery C). Kowalczyk was also considering the interpretation of the habit of burning bonfires in graves. He shares the opinion of Stanisław Ciszewski that the bonfire is an altar-mediator between the living ones and the ancestors'spirits and the entire transcendental world (Kowalczyk 1964b: 224).

The GAC occupies an important place in the famous dissertation of J. Kowalczyk: Poczatki neolitu na ziemach polskich [The Origins of the Neolithic Age on Polish Territories] (1969). Although this culture is classified (in chronological terms) as Later Neolithic, many researchers stress the participation of Mesolithic traditions in its emergence. For this reason, J. Kowalczyk included it in the discussion of the beginnings of the Later Stone Age. He considered that in the Polish territories, regardless of the time when it happened, early-Neolitic communities were also those belonging to cultures that originated from the Mesolithic substrate, undergoing neolithisation. According to this approach, the "early-Neolithic" cultures of this region would be not only the Linear Pottery culture, but also the TRB and the GAC cultures. The further part of the study is devoted to divagations about the definition, extent, territorial division, chronology, genesis, and the search for the "cradle" of the GAC.

Discussing the territorial division of this culture, J. Kowalczyk polemicized with Tadeusz Wiślański (1966a), who divided it into three great units: the western, Polish and the eastern ones. He also suggested the existence of a fourth group: the northern 
(or north-eastern)one, where, according to him, the "cradle" of this culture should be localisated.

In the further part of the study, J. Kowalczyk cites very different views on the chronology of the GAC: of Konrad Jażdżewski (Chmielewski, Jażdżewski and Kostrzewski 1965: II4-II5), of T. Wiślański (I966a: I27, I30; I966b: 20-2I, 24), of Valentin Weber (1964: 187), Hermann Behrens (1965: I, Fig. I), Tadeusz Sulimirski (I957-1959: 277). In his opinion, the beginnings of this culture did not reach the times corresponding to the older phase of the TRB settlement in Gródek nad Bugiem or the CI/CII phase of the Tripolye culture, and especially the times of the Stroke Ornamented Pottery culture. He believes that T. Sulimirski is also wrong in opting for the very late chronology of the GAC. However, in his opinion, the GAC is correctly dated to the third millennium BC.

Kowalczyk further considers three concepts of the localisation of the cradle of the GAC:

I) on the middle-Elbe -the concept once promoted by Nils Herman Niklasson (1925: 169), a Swedish archaeologist, working at the museum in Halle, and by German archaeologists: Ernst Sprockhoff (1926: 83; 1938: 129-130) and Hans Priebe (1938: 62-63), due to the significant concentration of sites of this culture in the area of the middle Elbe;

2) in the south-east (from the area of the Black Sea) - supported by V.G. Childe (1925) and Marija Gimbutas (1956: 150-I5I), for whom crucial was the occurrence of cist graves as well as animal burials, the characteristic position of the dead (on the side), the presence of collective graves - because according to their view these are the Black Sea and southern traits;

3) in the north - the concept created for nationalist reasons by German scholars, among others Gustav Kossinna (I9I0: 59), rejected with the fall of the Third Reich - according to which the GAC communities represent "early Germans" taking possession of the subsequent territories of Central Europe after leaving the northern territory. In later years, this concept was returned to, while rejecting the ethnic affiliation and clearly defining that it concerns an area from Kuyavia to eastern Brandenburg; these views were represented by T. Sulimirski (1957-1959: 276 and f.), T. Wiślański (1963: 259), and V. Weber (1964: 192).

Arguing against M. Gimbutas, J. Kowalczyk cited examples of deliberately chaotic arrangement of some skeletons (it is justified to see this as a ritual practice), while individuals "distinguished" ("main ones") were buried in an upright position. This last feature is undoubtedly borrowed from the north. On the other hand, he agrees that sprinkling bodies of dead people with ocher is a cultural element essentially taken over from the south-east, but considered this practice as secondary. 
I66 | Andrzej Bronicki

Generally, J. Kowalczyk was in favour of the northern "cradle" with some deviation to the east - to the area of the forest-Neolithic domain (as evidenced by the use of double-ended bone points and the brittleness of ceramics), which means questioning the hypothesis of T. Wiślański and others. According to J. Kowalczyk, the home area of the GAC should be located north of the Kuyavia region, which at that time was occupied by the TRB communities. According to this opinion, Kuyavia would have been an early but secondary centre of the GAC (repeating this idea after T. Sulimirski), and the real "cradle" should be sought in the area of the lower Vistula. This area was in close contact with the extent of the compact occurrence of the Pit-and-Comb Pottery culture in the east, and in the west, it was in contact with the megalithic idea spreading from the west, from the region of the lower Odra.

According to J. Kowalczyk, the stages of GAC development would be the following:

stage I: formation of a separate culture in the home area (in the "cradle"); stage 2: creation of a secondary centre in Volhynia (migration);

stage 3: population shifts from Volhynia to the west - to the Lublin region (expansion).

The author emphasizes the relationship of the GAC in its oldest phase with Mesolithic (retarded forest communities), manifested by the presence of trapezoidal projectile points.

The above-presented reflections were collected again in one place, in the popular science book Zmierzch epoki kamienia [The Twilight of the Stone Age] (I97Ic). It is not meaningful to repeat them. However, it is worth mentioning what the new publication brought to the knowledge of the GAC and understanding of this culture by J. Kowalczyk. The researcher made it clear that the probable factor triggering the crisis "after the period of stabilisation and prosperity", i.e. at the end of the Neolithic period, were large population movements caused by a catastrophic famine that affected the shepherds due to the destruction of pastures in the East European zone due to several years of drought. At that time, there was a strong secondary GAC centre in Volhynia, established as a result of migration from the north-west taking place along the eastern border of the TRB. This group had to move to the west, to the Lublin region covered by the settlement of the TRB communities, and to the south in the territory of the Tripolye culture. ${ }^{5}$ Expansion to the areas on the upper Bug would have been confirmed by the burning of the TRB settlement in Gródek, and the establishment of large TRB

s This view coincides with the opinion of T. Sulimirski, quoted by J. Kowalczyk (I97IC: IOI), who mentioned that in the Werteba cave in Bilcze Złote in Podolia, an "amphora" axe was found among the broken human bones of representatives of the Tripolye culture. 
settlements on the tops of the hills above the central Vistula River would be a response to the threat (from the GAC) from the east. The corded ornamentation, as well as "some other decorative motifs" in the TRB ceramics, would have been the result of the influence from the circle of the GAC.

In the further part of the work, the author reviewed opinions on the economic foundations and the lifestyle of the GAC population. He advocated against the thesis about the dominance of agriculture in this culture, because there are no large settlements in the areas it occupied. However, the presence of querns and grinding stones, as well as a grain impression on a vessel from Mierzanowice, is explained as testimony to obtaining grain from farmers from another culture or the existence of initial forms of agriculture. It is worth mentioning, however, that a few years later Zygmunt Krzak discovered such large settlements (Krzak 1983/1989: 270). The minor importance of hunting is shown by a definite quantitative dominance of the bones of domesticated animals over the wild ones in the settlement in Mierzanowice, but also in graves, where, however, found were boar's tusks and deer antlers. In addition, J. Kowalczyk believed that characterising the GAC community as "merchants" also does not correspond to the truth, because this statement can only apply to a small group of people, not the whole community. However, the frequent presence of weapons in graves justifies claiming the belligerent character of the representatives of this culture. Ultimately, J. Kowalczyk pronounced himself in favour of the view of the dominant role of the pastoral and breeding economy (after V. G. Childe). According to him, this state of affairs certainly prevailed in Volhynia and the Lublin region, although in the historical areas of East Prussia and Mazovia - not necessarily.

Further, J. Kowalczyk dealt with manifestations of the activity of the GAC peoples in the field of everyday life. He wrote that the building construction is hardly known, from that it can be concluded that the nomadic dwellings were light huts with a hearth, and the form of settlement was temporary camps. He makes review of the most important fields of manufacturing: flint, pottery, bone and amber processing. He dealt a bit more with evidence of exchange, writing about amber artefacts and cattle. He polemicized with the opinion that young cattle individuals could have been exchanged for axes of banded flint in the mining TRB settlement in Ćmielów. According to him, there is no certainty that Ćmielów was a mining settlement, and the remains of cattle found there did not have to have originated from their import from the population of the GAC, because cattle breeding was well known among the TRB communities. In addition, the GAC axes were rather not produced by representatives of the TRB, because their products were different. The author believed that the GAC had its own mining specialists. That the GAC could produce its own axes is shown by the fact that they were manufactured, among other things, in the GAC settlement in Mierzanowice. 
I68 Andrzej Bronicki

Then, turning to the beliefs and rituals, J. Kowalczyk mentioned cannibalism and ritual bonfires in the graves examined on the Nałęczów Plateau. Speaking of collective burials with the "main" individual, he stated that the victims could be both people killed during the funeral ceremonies and the remains of previously deceased people. Continuing the considerations regarding the funeral rite, J. Kowalczyk did not support the current views about the existing of the "megalithic religion", promoted by V. G. Childe, explaining that the megalithic grave is an artificial cave, probably invented independently in different cultures and in many areas. Further, he dedicated a few sentences to animal graves, which he had already interpreted elsewhere. Concluding this part of the considerations, J. Kowalczyk questioned the thesis about the patriarchal type of social relations, which he regarded as quite doubtful in view of the fact that in the Las Stocki collective grave, it was a woman who was the "distinguished" occupant.

In the conclusion, the author returns to the issue of the "cradle" of the GAC indicating the areas in the lower Vistula area on the border with the forest zone as the place of origin of this taxonomic unit. He also speaks about the huge role of the "amphoral" communities in the genesis of the Złota culture.

\section{THEORETICAL REFLECTIONS}

J. Kowalczyk devoted a lot of space in his scientific output to theoretical and methodological considerations on the problems of the Polish Neolithic and research postulates regarding his favorite epoch. In the entire cycle of this type of work, the GAC appears quite often, but usually is recalled as an illustration of some general theses. Undoubtedly an important statement is the opinion of Kazimierz Tymieniecki, shared by J. Kowalczyk, that during the Neolithic the basic core of the population living in the Odra and Vistula basin did not undergo any major changes (Tymieniecki 1952: 15; Kowalczyk 1962a: 279). This remark also applies to the GAC, which was formed, according to Kowalczyk, as a result of the gradual neolithisation of local Mesolithic communities (Balcer 1998: V), which can be confirmed by the presence of finds of "Janisławice" type (trapezoid projectile points) in its inventories (Kowalczyk I97Ib: 250; cf. also Balcer 197I).

In considerations concerning the chronology of the Later Stone Age, we also find reflections referring to the GAC. Kowalczyk was aware that in its traditional division into the older and younger phase, the significance of presence of corded ornamentation or its lack needed to be thrown into question. He believed the researchers for whom the appearance of cord imprint is a determinant of its later developmental period were incorrect (Kowalczyk 1971a: 408; 1976: 182; also 1977: 7). At the same time, he thought 
that there was a certain contemporaneity of the GAC and the final phase of the Tripolye culture (I97Ib: 250).

Among the research postulates concerning the GAC whose topicality is incontestable, the necessity to conduct research on the settlements that were "difficult to detect" (Kowalczyk 1971a: 406) must be mentioned. This results from the fact that the previous scope of cognition of this culture had a very one-sided character because it was largely based on the examination of graves (Kowalczyk 1963: 70).

Another interesting idea of J. Kowalczyk was the postulate of making an inventory of all the places where there are concentrations of stones on the loess fields of the Lublin region. Because in large part, they may be archaeological sites - damaged grave features with stone structures. Radio and television (Kowalczyk 1975: 3I) would have their part in collecting information from residents.

In a text discussing the possibilities and necessity of cooperation with auxiliary sciences of archaeology, among others with anthropology, J. Kowalczyk, convinced of the importance of anthropological types for the reconstruction of migration and intratribal relations, claims that in this respect human remains from collective graves should be investigated more widely than they had previously been (Kowalczyk I968c: 84).

\section{DISCUSSIONS AND REVIEWS}

This form of scientific expression was used by J. Kowalczyk quite rarely. Only two published works of this nature have been found in his entire output (I959a and 1977). The first is a review of an English-language prehistoric synthesis by M. Gimbutas, discussing the prehistory of Eastern Europe, including the Polish territories (Gimbutas I956). J. Kowalczyk agrees with the thesis which the author quotes after Włodzimierz Antoniewicz that the Złota culture has very serious references to the GAC. Her arguments regarding the "cradle" of this culture also appealed to him, which he stated as follows: the Author's reasoning justifying the eastern origin of the Globular Amphora culture, more precisely from the area north of the Black Sea deserves attention (Kowalczyk I959a: 269) to what can - in his opinion - indicate also the foreign character of this culture in the TRB environment in the Lublin region and the destruction of the settlement in Gródek by invaders from the east. It is worth noting here that this position was soon abandoned by J. Kowalczyk in favor of the thesis about the northern "cradle" (in the area of lower Vistula). The scholar disputes, however, with M. Gimbutas' opinion about the presence of the GAC graves in the multicultural cemetery in Mierzanowice, because he thinks that they are not there at all (but there are graves of the "Mierzanowice" and "Złota" cultures as well as "corded" graves). He appreciated the work of M. Gimbutas as a "valuable" work that "gives a broad overview of the evidence and issues". 
I7o $\mid$ Andrzej Bronicki

The second text is an Introduction to the collective book he edited - a monograph of the GAC cemetery "Gajowizna" in Złota, Sandomierz district: Cmentarzysko kultury amfor kulistych $w$ Ztotej Sandomierskiej [Cemetery of the Globular Amphora Culture in Ztota Sandomierska] (Wrocław 1977), provided with chapters written by an archaeologist (Z. Krzak), anthropologist (B. Miszkiewicz) and archaeozoologists (K. Krysiak and A. Lasota-Moskalewska). A completely new observation, included in the publication, and appreciated by J. Kowalczyk, is the existence of "comprehensive, multisegmented" burial grounds, where the chamber with human remains is accompanied even by three additional features (previously it was thought that there could be at most one, and that this phenomenon occurs quite rarely). The fact of the existence of such foursegment complexes undermines - according to J. Kowalczyk - the thesis of the antecedence of ceramics without cord ornamentation, because in inventories of features constituting part of a complex constructed in one action can occur both ceramic finds decorated with cord ornaments and without it. Kowalczyk also points out the archaic nature of the racial traits of three determinated individuals with a paleoeuropoid and laponoidal components and lack of remains of old men. He also refers to the results of archaeozoological analysis, which showed that the cattle of the GAC community from Zlota had a more primitive character than those identified on other sites of this culture, while beingclose to the cattle of the TRB community. The author of the Introduction sums up the publication by suggesting that the accumulation of archaic features justifies the need to create new hypotheses regarding the genesis of the GAC, and "even the entire Neolithic".

\section{ENCYCLOPEDIA ENTRIES}

Already in the mid-sixties, J. Kowalczyk was considered an outstanding expert on the Late Stone Age. This opinion probably decided that the editors of the thirteen volume Wielka Encyklopedia Powszechna PWN [PWN Great Universal Encyclopedia] entrusted him with the writing of the entry "Neolithic", published in the seventh volume of the publication (1966: 282-283). In the context of the comprehensive view of this period presented there, the GAC takes little space. The author, in accordance with his views previously presented elsewhere, speaks of the Central European origin of this taxonomic unit and treats it as one of the elements of the Final Neolithic "great population movements" that "caused the decline of the Black Sea and Central European" cultures experiencing at that time a heyday. He treats the GAC as a disintegrating and destructive factor (next to the communities of the Corded Ware culture).

Kowalczyk was also the author of the entry "Amfor kulistych kultura" [Amphora Globular culture] in the Encyklopedia sztuki starożytnej. Europa, Azja, Afryka, Ameryka [Encyclopedia of Ancient Art. Europe, Asia, Africa, America] (1974a: 48-49). It is not 
signed by name, but the authors of his obituary include it among the achievements of the scholar (Zakościelna and Gurba 2007: 387). The text starts with an explanation of the origin of the name (from the characteristic form of the vessel - amphora). It then gives the current ideas of the dating (2500-2000 BC), extent (from the Elbe to the Dnieper and Moldova), economic foundations (pig and cattle breeding). It characterizes the forms of settlement (small, indigent camps, lacking traces of houses or dugouts), mentions the production of axes from banded flint and the emphasized the role of amber as a raw material for making ornaments. The author briefly describes the funerary architecture and the rite (stone chambers, lack of cremation, frequent collective burials with one "distinguished" deceased, accompanied by human victims), cannibalism, animal graves (of cattle). He concludes that these are unique characteristics distinguishing the GAC from other cultures. He evaluates its prehistoric role negatively by writing: No doubt it contributed to the breakdown of the structures of older farming communities (1974a: 49).

The same publication contains one more entry by J. Kowalczyk: "Neolithic" (1974b: 337). Although the name GAC does not appear here at all, one can guess that the statements about the practiced funeral rite (inhumation) and the dissemination of the megalithic idea also apply to the "amphoral" communities, and the opinion that [...] some peoples practiced cannibalism, also offerings of human and animal sacrifices were brought to the dead, refers in particular to the communities of this culture.

\section{SUMMARY}

Jan Kowalczyk was a researcher of the Neolithic who marked his presence in the process of understanding the GAC in the following ways:

I) Looking for a "cradle", he modified the concept of a northern localization of its home territories, pointing to the area of the lower Vistula, at the interface with the Pit-and-Comb Pottery culture, in the zone of megalithic influences reaching from west of the lower Odra. He excluded the origin of the GAC from the Black Sea steppes.

2) He linked the chronology of the GAC to the third millennium BC, indicating that the $\mathrm{FBC}$ was older than it, and pointing to its contemporaneity with the youngest duration period of the Tripolye culture and partly with the Corded Ware culture. When considering whether the GAC can be included among Early Neolithic cultures, he accepted this idea, however, only in the sense of the degree of neolithisation of the Mesolithic substrate (adopting a new economic model). In reference to the absolute chronology, he argued that it is a taxonomic unit that must be assigned 
to the Late Neolithic. As to its periodisation, Kowalczyk rejected the use of the impressed cord ornamentation as a dating element.

3) He pointed to the dominant role of mobile breeding in the economy of the GAC (with the possibility of initial farming and some role of hunting); it must be mentioned here that this was not a widely accepted view at that time.

4) Analysing the funeral ritual, J. Kowalczyk came to the conclusion that in collective graves one can distinguish the "main" individual and human "sacrifices", which constituted a new concept in interpreting graves of the GAC, previously considered as "family burials". It is interesting to note his statement that this "distinguished" person could have been a woman; this thesis called into question the view of patriarchal intra-group relations in this community.

5) Reflecting on Neolithic demographics, J. Kowalczyk concluded that in the Polish territories the core of the Neolithic population, throughout the entire epoch was the same (Kowalczyk 1962a: 279), while at that time prevailing was an opinion of relentless migrations and influx of new waves of settlers. However, he also recognized that the GAC was an alien element, a destructive factor, arriving in the Lublin region from Volhynia (from the secondary centre), which initiated the Late Neolithic migrations and contributed to the collapse of the FBC and of the Tripolye culture at their cultural apogee.

6) Also important are the thoughts of J. Kowalczyk regarding the methodology of the archaeological research. In particular, he pointed out that the graves of the GAC should be examined together with their surroundings, which makes it possible to discover the accompanying features.

7) The thoroughness and precision of the excavations of J. Kowalczyk deserves to be emphasized, as well as the high substantive quality of his reports on graves of the GAC, usually containing anthropological and archaeozoological expert reports (this was not a common phenomena at the time) and the use of radiocarbon dating to chronological considerations, which puts J. Kowalczyk among the pioneers of using this method in Poland.

Translated by Andrzej Leligdowicz

\section{REFERENCES}

Balcer, B. 1971. O stanie i potrzebach w zakresie badań krzemieniarstwa neolitu i wczesnej epoki brązu. Wiadomości Archeologiczne 36: 5I-70.

Balcer, B. 1998. Jubileusz osiemdziesięciolecia docenta dr. hab. Jana Kowalczyka. Archeologia Polski 43(I-2): III-V.

Bronicki, A. 2000.Grób kultury amfor kulistych w Kolonii Czułczyce, stan. 6, gm. Sawin, pow. Chełm, woj. Lublin. Archeologia Polski Środkowowschodniej 5: I8I-I92. 
Bronicki, A. 2016. Obrządek pogrzebowy społeczności kultury amfor kulistych na Wyżynie Lubelskiej. In P. Jarosz, J. Libera and P. Włodarczak (eds), Schytek neolitu na Wyżynie Lubelskiej, 45-256. Kraków.

Bronicki, A. 20I9. Chronologia podgrupy wschodniolubelskiej kultury amfor kulistych w świetle oznaczeń radiowęglowych. In M. Szmyt, P. Chachlikowski, J. Czebreszuk, M. Ignaczak and P. Makarowicz (eds), Vir Bimaris. Od kujawskiego matecznika do stepów nadczarnomorskich. Studia z dziejów międzymorza battycko-pontyjskiego ofiarowane Profesorowi Aleksandrowi Kośko. Poznań, 20I-228. Archaeologia Bimaris. Dyskusje 5.

Childe, V. G. 1925. The Dawn of European Civilisation. London.

Chmielewski, W., Jażdżewski, K. and Kostrzewski, J. 1965. Pradzieje Polski. Wrocław-WarszawaKraków.

Dzierżykraj-Rogalski, T. 1948. Szczątki kostne z grobu kultury amfor kulistych w Stoku w powiecie puławskim. Annales Universitatis Mariae Curie-Sktodowska, sectio F, vol. 2(1947): 235-254.

Dzierżykraj-Rogalski, T. 1955. Długość trwania życia człowieka neolitycznego na ziemiach polskich. Rocznik Akademii Medycznej w Biatymstoku I: 77-90.

Gabałówna, L. 1958. Pochówki bydlęce kultury amfor kulistych ze stanowiska 4 w Brześciu Kujawskim w świetle podobnych znalezisk kultur środkowoeuropejskich. Prace i Materiaty Muzeum Archeologicznego i Etnograficznego w Eodzi, Seria Archeologiczna 3: 63-I07.

Gimbutas, M. 1956. The Prehistory of Eastern Europe, Part I, Mesolithic, Neolithic and Copper Age Cultures in Russia and the Baltic Area. Cambrige, Massachusetts. Bulletin, No 20.

Halicki, M. I970. Cmentarzyska kultury amfor kulistych i kultury pucharów lejkowatych w Klementowicach, pow. Puławy na stanowisku IV. Wiadomości Archeologiczne 35: 303-326.

Jażdżewski, K. 1937. Dotychczasowe wyniki badań archeologicznych na Kujawach w r. 1937. Z otchtani wieków 12(7-8): 95-106.

Kossinna, G. 19I0. Der Ursprung der Urfinnen und Urindogermanen und ihre Ausbreitung nach Osten. Mannus 2: 58-108.

Kostrzewski, J. 1930. Neolityczny grób skrzynkowy ze Skoczki w pow. szubińskim. In J. Kostrzewski (ed.), Ksiega pamiątkowa ku uczczeniu siedemdziesiątej rocznicy urodzin prof. dr. Wtodzimierza Demetrykiewicza, 93-100. Poznań.

Kostrzewski, J. 1939-1948. Od mezolitu do okresu wędrówek ludów. Prehistoria ziem polskich. Kraków. Encyklopedia polska, t. IV.

Kowalczyk, J. 1949. Nowe odkrycia prehistoryczne. Województwo lubelskie. Nowe stanowiska archeologiczne na Lubelszczyźnie. $Z$ otchtani wieków 18(9-10): 155-156.

Kowalczyk, J. 1951. Obrzadek pogrzebowy w mtodszej epoce kamiennej na ziemiach polskich. Unpublished $\mathrm{PhD}$ thesis, Maria Curie-Skłodowska University in Lublin.

Kowalczyk, J. 1953. Dwa groby kultury amfor kulistych z Lasu Stockiego i Stoku, pow. Puławy. Sprawozdania P.M.A. 5(I-2): $38-47$.

Kowalczyk, J. 1957. Osada i cmentarzysko kultury pucharów lejkowatych w miejscowości Klementowice, powiat Puławy. Materiaty Starożytne 2: 175-202.

Kowalczyk, J. 1959a. rec.: M. Gimbutas: The Prehistory of Eastern Europe, Part I, Mesolithic, Neolithic and Copper Age Cultures in Russia and the Baltic Area, "Bulletin No 20", Cambrige Massacchusets 1956. Rocznik Olsztyński 2: 268-269.

Kowalczyk, J. 1959b. “Złoty wiek” Lubelszczyzny w młodszej epoce kamienia. Z otchtani wieków 25(3): $172-176$.

Kowalczyk, J. 1962a. Uwagi o problematyce i postulatach badawczych neolitu polskiego. Wiadomości Archeologiczne 27: 27I-282.

Kowalczyk, J. I962b. Zagadnienie grobów zbiorowych w neolicie Polski. Wiadomości Archeologiczne 28: I-I2. 
I74 Andrzej Bronicki

Kowalczyk, J. 1963. Niektóre problemy polskiego neolitu w świetle nowszych badań. Prace i Materiaty Muzeum Archeologicznego i Etnograficznego w Eodzi, Seria Archeologiczna 10: 65-75.

Kowalczyk, J. 1964a. Lud kultury amfor kulistych, część I. Z otchtani wieków 30(3): 146-I55.

Kowalczyk, J. 1964b. Lud kultury amfor kulistych, część II. Z otchtani wieków 30(4): 217-225.

Kowalczyk, J. 1966. Neolit. In Wielka encyklopedia PWN, t. 7, 282-283. Warszawa.

Kowalczyk, J. 1968a. Dwa zespoły neolityczne datowane radiowęglem. Wiadomości Archeologiczne 33: $368-376$.

Kowalczyk, J. 1968b. Radiowęglowe datowania neolitu Małopolski. Sprawozdania z Posiedzeń Komisji Naukowych Oddziatu PAN w Krakowie: 2I-22.

Kowalczyk, J. 1968c. Zagadnienie przeobrażeń kulturowych w neolicie. In A. Nadolski (ed.), Na granicach archeologii, 77-85. Łódź. Acta Archaeologica Lodziensia 17.

Kowalczyk, J. 1969. Początki neolitu na ziemiach polskich. Wiadomości Archeologiczne 34(I): 3-69.

Kowalczyk, J. 1971a. Główne problemy polskiego neolitu. Sprawozdania Archeologiczne 23: 405-409.

Kowalczyk, J. I97Ib.W związku z dyskusją nad początkami neolitu. Wiadomości Archeologiczne 36: $243-252$.

Kowalczyk, J. 1971c. Zmierzch epoki kamienia. Wrocław.

Kowalczyk, J. 1973. Źródtoznawcza problematyka archeologii. In $Z$ badań nad neolitem i wczesna epoka brazu w Matopolsce: 9-18. Prace Komisji Archeologicznej I2.

Kowalczyk, J. 1974a [unsigned]. Kultura amfor kulistych. In A. Gogut, G. Hartwig and A. Dulewicz (eds), Encyklopedia sztuki starożytnej. Europa, Azja, Afryka, Ameryka, 48-49. Warszawa.

Kowalczyk, J. 1974b [unsigned]. Neolit. In A. Gogut, G. Hartwig and A. Dulewicz (eds), Encyklopedia sztuki starożytnej. Europa, Azja, Afryka, Ameryka, 337. Warszawa.

Kowalczyk, J. 1975. Postulaty badawcze neolitu Lubelszczyzny. In J. Gurba [unsigned]. XXX lat archeologicznych prac badawczych i konserwatorskich $w$ Lublinie, 29-3I. Lublin.

Kowalczyk, J. 1976. Die Gliederungsprobleme des polnischen Neolithikums. Archaeologia Polona I7: I77-I83.

Kowalczyk, J. I977. Wstęp. In J. Kowalczyk (ed.), Cmentarzysko kultury amfor kulistych w Ztotej Sandomierskiej, 7-8. Wrocław.

Kozłowski, L. 1921. Groby megalityczne na wschód od Odry. Prace i Materiaty Antropologiczno-Archeologiczne i Etnograficzne 2: I-63.

Krzak, Z. 1983/1989. Nowe stanowiska neolityczne i wczesnobrązowe w dorzeczu Gierczanki na Wyżynie Sandomierskiej. Wiadomości Archeologiczne 49(2): 26I-27I.

Maringer, J. I942-I945. Menschenopferim Bestattungsbrauch Alteuropas. Anthropos 37-40: I-II2.

Niklasson, H. 1925. Studienüber die Walternieburg-Bernburger Kultur. Jahresschriftfür die Vorgeschichte der sächsisch-thüringischenLänder I3: I-I85.

Nosek, S. 1951. Obrządek pogrzebowy w młodszej epoce kamiennej na ziemiach polskich. Sprawozdania z czynności i posiedzeń Polskiej Akademii Umiejętności 52: 931-933.

Nosek, S. 1954-1955. Kultura amfor kulistych na Lubelszczyźnie. Annales Universitatis Mariae Curie-Sklodowska, sectio F, vol. V (1950): 55-158.

Nosek, S. 1967. Kultura amfor kulistych $w$ Polsce. Wrocław.

Priebe, H. 1938. Die Westgruppe der Kugelamphoren. Jahresschrift für die Vorgeschichte der sächsischthüringische Länder 28: I-I44.

Reimer, P. J., Bard, E., Bayliss, A., Beck, J. W., Blackwell, P. G., Bronk Ramsey, C., Buck, C. E., Cheng, H., Edwards, R. L., Friedrich, M., Grootes, P. M., Guilderson, T. P., Haflidason, H., Hajdas, I., Hatté, C., Heaton, T. J., Hoffmann, D. L., Hogg, A. G., Hughen, K. A., Kaiser, K. F., Kromer, B., Manning, S. W., Niu, M., Reimer, R. W., Richards, D. A., Scott, E. M., Southon, J. R., Staff, R. 
A., Turney, C. S. M. and von der Plicht, J. 2013. IntCalı3 and Marineız Radiocarbon Age Calibration Curves 0-50.000 Years cal BP. Radiocarbon 55(4): I869-1887.

Sawicki, L. 1920. Groby megalityczne w Potyrach, pow. płoński ziemi warszawskiej. Wiadomości Archeologiczne 5: I25-I4I.

Sprockhoff, E. 1926. Die Kulturen der jüngeren Steinzeit in der Mark Brandenburg. Vorgeschichtliche Vorschungen I: I-I83.

Sprockhoff, E. 1938. Die nordische Megalithkultur. Berlin-Leipzig. Handbuch der Urgeschichte Deutschlands 3 .

Sulimirski, T. 1957-1959.Polska przedhistoryczna, cz. II. Londyn.

Tymieniecki, K. 1952. Migracje w Europie środkowo-wschodniej w starożytności. Slavia Antiqua 3: I-47.

Uzarowiczowa, A. and Kowalczyk, J. 1973. Cmentarzysko kultury amfor kulistych w Bieniewie, pow. Pruszków. Wiadomości Archeologiczne 38: I69-179.

Weber, V. 1964. Die Kugelamphorenkultur in Sachsen. Arbeits- und Forschungsberichte zur sächsischen Bodendenkmalpflege 13: 73-192.

Wiślański, T. 1963. Próba wyświetlenia genezy tzw. kultury amfor kulistych, Archeologia Polski 8(2): 222-245.

Wiślański, T. 1966a. Kultura amfor kulistych w Polsce pótnocno-zachodniej. Wrocław. Polskie Badania Archeologiczne I3.

Wiślański, T. 1966b. Über die territorialen und chronologischen Einteilungen der Kugelamphorenkultur. Archaelogia Polona 9: 7-26.

Włodarczak, P. 20I6. Chronologia absolutna cmentarzysk późno- i schyłkowoneolitycznych na Wyżynie Lubelskiej. In P. Jarosz, J. Libera and P. Włodarczak (eds), Schytek neolitu na Wyżynie Lubelskiej, 537-548. Kraków.

Zakościelna, A. 1997. Bibliografia prac archeologicznych i publicystyki katolickiej Doc. Dra hab. Jana Kowalczyka bytego kierownika Katedry Archeologii UMCS. Lublin. Archeologiczne Listy I (50).

Zakościelna, A. and Gurba, J. 2007. Doc. Dr. hab. Jan Kowalczyk (23.I0.1918-25.0I.2007). Archeologia Polski Środkowowschodniej 9: 384-387. 
